JiiP Volume 5 Nomor 2: 66-76, Desember 2019 Jurnal Ilmu dan Industri Peternakan pISSN 2355-0732, eISSN 2716-2222

http://journal.uin-alauddin.ac.id/index.php/jiip/index DOI https:/ / doi.org/10.24252/jiip.v5i2.11883

\title{
Konsumsi Ransum, Pertambahan Bobot Badan dan Konversi Ransum Ayam Kampung Super yang Diberikan Ransum mengandung Tepung Pistia stratiotes
}

\author{
Consumption Ration, Weight Gain, and Conversion of Super Kampung Chicken \\ Ration given rations containing Pistia stratiotes Flour \\ Rusli*, Muhammad Nur Hidayat, Rusny, Andi Suarda, Jumriah Syam, Astati \\ Jurusan Ilmu Peternakan Fakultas Sains dan Teknologi \\ Universitas Islam Negeri Alauddin, Makassar \\ Kampus II.Jl.H.M.Yasin Limpo No 36, Romang Polong-Gowa- Indonesia \\ Kode Pos 9211; Telp (0411) 841879; Fax(0411) 8221400 \\ *Korespondensi Email: muhammadrusli014@gmail.com
}

\begin{abstract}
ABSTRAK
Pistia stratiotes merupakan tanaman air yang dianggap gulma bagi petani padi, tetapi memiliki nutrisi yang tinggi, yaitu kandungan air 16,9\%, protein kasar $35,7 \%$, lemak kasar 7,6\%, serat kasar $15,6 \%$, bahan ekstrak tanpa nitrogen (BETN) $16,6 \%$ dan abu $24,0 \%$. Tujuan penelitian ini untuk mengetahui pengaruh tepung apu-apu dalam ransum terhadap performa ayam kampung super dan potensi tepung apu-apu dalam mensubtitusi bahan pakan lain. Jenis penelitian kuantitatif dengan menggunakan metode Rancangan Acak Lengkap (RAL) dengan 5 perlakuan 3 kali ulangan, P0 (kontrol), P1 (5\% apu-apu), P2 (10\% apuapu), P3 (15\% apu-apu) dan P4 (20\% apu-apu). Parameter yang di ukur adalah konsumsi ransum, pertambahan bobot badan, konversi ransum. Hasil sidik ragam menunjukkan penelitian ini tidak berpengaruh nyata $(P>0,05)$ terhadap performa ayam kampung super.
\end{abstract}

Kata kunci: Ayam Kampung Super, Performa, Apu-Apu

\begin{abstract}
Apu-apu flour (Pistia stratiotes) is a water plant that is considered a weed for rice farmers but has high nutrition, namely $16.9 \%$ water, $35.7 \%$ crude protein, $7.6 \%$ crude fat, $15.6 \%$ crude fiber, BETN is $16.6 \%$ and ash is $24.0 \%$. The purpose of this study was to determine the effect of apu-apu flour in rations on the performance of super chicken and the potential of apu-apu flour in substituting other feed ingredients. This type of quantitative research uses the Completely Randomized Design (CRD) method with 5 treatments 3 replications, P0 (controls), P1 (5\% apu-apu), P2 (10\% apu-apu), P3 (15\% apu-apu) and P4 (20\% apu-apu). The parameters measured are ration consumption, body weight gain, ration conversion. The results of variance showed that this study had no significant effect $(\mathrm{P}>0.05)$ on the performance of super chicken.
\end{abstract}

Keywords: Stress, Malondialdehyde, Creatinin, Duck 


\section{PENDAHULUAN}

Indonesia merupakan negara yang memiliki iklim yang cukup baik bagi ternak untuk hidup, ternak mudah menyesuaikan diri dengan lingkungan sehingga dalam mengembangkan peternakan tidak terlalu sulit. Disisi lain juga memiliki berbagai jenis tanaman yang berpotensi dijadikan bahan pakan untuk ternak.

Dunia peternakan memiliki banyak pilihan yang bisa kita jadikan sebagai pekerjaan tetap sebab prospeknya sangat menunjang kedepannya untuk memenuhi kebutuhan hidup yang setiap tahunnya terus mengalami peningkatan, dalam hal perekonomian. Berwirausaha di bidang perunggasan merupakan salah satu bidang usaha yang banyak dilirik masyarakat Indonesia saat ini karena usaha ini cukup menjanjikan untuk dikembangkan kedepannya apalagi kebutuhan daging ayam yang semakin meningkat setiap tahunnya sedangkan ketersediaan yang masih terbatas. Widiati (2014) menyatakan bahwa konsumsi daging dalam negeri $70 \%$ berasal dari ternak unggas. Hal ini disebabkan kesadaran masyarakat tentang pentingnya hidup sehat dan daging ayam salah pilihan masyarakat karena harganya yang relatif murah.

Salah satu usaha di bidang unggas yang banyak dikembangkan adalah ayam kampung super sebab ayam ini mudah dalam pemeliharaannya, memiliki masa panen yang cepat serta tahan terhadap penyakit berbeda dengan ayam broiler atau ayam petelur yang saat ini semakin sulit dalam pemeliharaannya. Sebagaimana yang dilaporkan oleh Widodo (2014), bahwa pertumbuhan ayam kampung super lebih cepat daripada ayam kampung lokal. Daging ayam kampung super peminatmya sangat banyak dan stok daging masih kurang. Hal ini karena masyarakat kelas menengah atas kian meningkat perekonomiannya.

Pertumbuhan ayam kampung super lebih cepat dibandingkan kampung biasa karena sudah mengalami perbaikan genetik yang terus dilakukan oleh ilmuan yang bergerak di bidang peternakan, dengan didapatkannya strain yang baru maka diharapkan bisa memenuhi kebutuhan swasembada daging dalam negeri sehingga peternak ayam kampung super bisa mencapai kesejahteraan. Performa ayam kampung super sangat ditunjang oleh ransum yang berkualitas, dimana semua kebutuhan nutrisi yang dibutuhkan olah ternak dapat di sediakan sehingga dapat menghasilkan produktivitas yang tinggi tetapi kita perlu juga pertimbangkan masalah ekonomi pakan karena pakan komersial cukup mahal sehingga sangat mempengaruhi keberhasilan peternak. 
Konsumsi ransum pada ayam kampung super sangat menunjang dalam meningkatkan produktivitas sehingga membuat para peternak maupun para peneliti terus mencari pakan yang berkualitas. Menyatakan jumlah pakan yang dikonsumsi oleh ternak digunakan untuk mencukupi hidup pokok dan produksi (Tilman dkk. 1991). Faktor yang mempengaruhi konsumsi ransum antara lain besar tubuh ayam, aktivitas sehari-hari, suhu lingkungan, kualitas dan kuantitas ransum (NRC, 1994).

Kualitas ransum dapat dilihat dari bagaimana ternak dapat memanfaatkan seefisien mungkin ransum yang dikonsumsi untuk dijadikan sebagai energi maupun dalam meningkatkan produksi, disisi lain konversi ransum sangat menunjang dalam keberhasilan peternak. Rasyaf (1995) menyatakan bahwa konversi ransum merupakan suatu ukuran yang dapat digunakan untuk menilai efisiensi penggunaan dan kualitas ransum. Konversi ransum adalah perbandingan antara jumlah ransum yang dikonsumsi dengan pertambahan bobot badan dalam jangka waktu tertentu.

Pakan yang baik adalah pakan memiliki nutrisi yang mampu dimamfaatkan oleh tubuh ternak untuk diubah menjadi produk baik itu daging maupun telur. Tetapi dengan tingginya biaya pakan maka kita pelu mencari pakan alternatif tetapi berkualitas sehingga bisa menurunkan biaya pakan sebagaimana yang di ungkapkan Nitis (1980) bahwa biaya pakan mencapai $60-70 \%$. Melihat banyaknya biaya yang dikeluarkan maka perlu adanya ransum murah, berkualitas, kontinyu dan mudah didapatkan.

Kebutuhan protein ayam kampung super berdasarkan umur pertumbuhan, umur 11,5 bulan kadar protein 18-22\%, umur 1,5- 3 bulan kadar protein 16-18\% sedangkan umur 3 bulan keatas $15-16 \%$. Ayam kampung super membutuhkan protein lebih rendah dibandingkan ayam broiler maupun ayam ras petelur (Agustina, 2013).

Apu-apu (Pistia stratiotes) merupakan tumbuhan air yang biasa dijumpai diperairan tenang, kolam ikan atau di sawah sebagai gulma yang mengganngu pertumbuhan padi serta tanaman ini meresahkan para petani jika ingin membunuhnya, harus memakai pestisida yang ampuh. Kandungan nutrisi Apu-apu (Pistia stratiotes) protein kasar, lemak kasar, nilai kecernaan yang cukup tinggi. Sedangkan cara mengembangbiakkannya sangat mudah, cukup dengan memisahkan anakan yang tumbuh dari batang jalurnya lalu kita pindahkan ke tempat yang lain. Jika ditinjau dari kandungan nutrisinya, tanaman apu-apu dapat dijadikan sebagai bahan penyusun pakan ternak dan dikelola dalam bentuk tepung sebab 
dalam bentuk tepung pemberiannya lebih mudah dalam menyusun ransum ayam serta pengolahannya tidak menurunkan kandungan nutrisinya

\section{METODE}

\section{Prosedur Penelitian}

Penelitian ini menggunakan alat-alat yang umum digunakan dalam pemeliharaan unggas yaitu kandang litter, lampu LED 15 watt 2 buah, tempat pakan, tempat air minum $800 \mathrm{ml}$, ember, palu, pisau, tenda (tirai), tali rapia, kantong plastik, dan timbangan digital sadangkan bahan yang digunakan yaitu Ayam Kampung Super umur 3 bulan sebanyak 45 ekor dengan jenis kelamin campuran (unsexed), tepung apu-apu (Pistia stratiotes). Sebelum menjadi tepung, apu-apu (Pistia stratiotes) diambil di sawah dan dibersihkan dari lumpurnya serta menghilangkan akarnya kemudian di keringkan selama 2-3 hari, selanjutnya dipabrik dalam bentuk tepung yang siap dicampurkan dalam ransum penelitian.

Rancangan Penelitian

Rancangan penelitian yang diterapkan pada penelitian ini adalah Rancangan Acak Lengkap yang terdiri dari 5 perlakuan dan 3 kali ulangan. Dimana setiap ulangan terdiri dari 3 ekor ayam kampung super sehingga jumlah keseluruhan ayam yang digunakan adalah 45 ekor, bahan yang digunakan pada perlakuan P1 sampai P4 dengan komposisi 5\% sampai $20 \%$ karena bahan ini masih baru dalam penerapannya pada ternak selain itu memiiki kandungan serat kasar yang agak tinggi. Adapun perlakuannya $(\mathrm{P})$, yaitu:

P0: Pemberian pakan standar tanpa menggunakan tepung apu-apu

P1: Pemberian pakan strandar dengan tambahan $5 \%$ tepung apu-apu

P2: Pemberian pakan standar dengan tambahan $10 \%$ tepung apu-apu

P3: Pemberian pakan standar dengan tambahan 15\% tepung apu-apu

P4: Pemberian pakan standar dengan tambahan 20\% tepung apu-apu

2. Persiapan dan Pemeliharaan Ayam Kampung Super

Persiapan yang dilakukan sebelum pemeliharaan ayam kampung super dalam penelitian ini yaitu:

a. Kandang

Sebelum ayam sampel penelitian dimasukkan ke dalam kandang, terlebih dahulu dilakukan sanitasi. Sanitasi kandang dilakukan dengan menyemprot air yang dicampur dengan detergen kemudian diberikan sekam disetiap sekat dengan ketebalan 7-10 cm, serta 
setiap sekat terdapat tempat pakan dan minum. Kandang yang digunakan seluas $60 \times 60 \mathrm{~cm}$ setiap sekat. Ayam kampung super dipelihara dari umur 90 hari sampai umur 118 hari (fase finisher). Jumlah ayam yang digunakan sebanyak 45 ekor yang dipilih secara acak dengan jenis kelamin yang berbeda, setiap perlakuan terdiri dari 3 ekor ayam kampung super.

b. Pakan

Pemberian ransun dan air minum diberikan secara adlibitum setiap harinya selama 4 minggu. Ransum pada perlakuan P0 tidak menggunakan tepung apu-apu (Pistia stratiotes). P1 penambahan tepung apu-apu (Pistia stratiotes) ke dalam ransum sebanyak 5\%. Perlakuan P2 penambahan tepung apu-apu (Pistia stratiotes) ke dalam ransum sebanyak $10 \%$. Perlakuan P3 penambahan tepung apu-apu (Pistia stratiotes) ke dalam ransum sebanyak 15\%. Perlakuan P4 penambahan tepung apu-apu (Pistia stratiotes) ke dalam ransum sebanyak $20 \%$. Selama penelitian berlangsung pengambilan data dilakukan setiap minggu dengan mengukur konsumsi pakan, pertambahan berat bada dan konversi ransum.

Susunan ransum penelitian disajikan pada Tabel 1 dan kandungan nutrisi ransum penelitian disajikan pada Tabel 2:

Tabel 1. Bahan Penyusun Ransum Penelitian

\begin{tabular}{lccccc}
\hline \multirow{2}{*}{\multicolumn{1}{c}{ Bahan pakan }} & P0 & P1 & P2 & P3 & P4 \\
\cline { 2 - 6 } & 59 & 59 & 59 & 59 & 59 \\
Jagung (\%) & 20 & 19 & 18 & 16 & 15 \\
Dedak (\%) & 4 & 2 & 1 & 2 & 1 \\
Tepung ikan (\%) & 17 & 15 & 12 & 8 & 5 \\
Bungkil kedelai (\%) & 0 & 5 & 10 & 15 & 20 \\
Tepung Apu-apu (\%) & (1)
\end{tabular}

Keterangan: P0 (Kontrol), P1 (5\% Apu-apu), P2 (10\% Apu-apu), P3 (15\% Apu-apu) dan P4 (20\% Apu-apu).

Tabel 2. Kandungan Nutrisi Ransum Penelitian

\begin{tabular}{lccccc}
\hline \multirow{2}{*}{ Kandungan Nutrisi } & $\mathbf{5}$ & $\mathbf{P 1}$ & $\mathbf{P 2}$ & $\mathbf{P 3}$ & $\mathbf{P 4}$ \\
\cline { 2 - 6 } & 16,2 & 16,11 & 16,12 & 16,3 & 16,30 \\
\hline Protein (\%) & 2823,26 & 2822,58 & 2821,69 & 2825,28 & 2825,39 \\
EM (Kkal/kg) & 5,29 & 5,46 & 5,66 & 5,8 & 6 \\
Lemak kasar (\%) & 4,64 & 5,18 & 5,67 & 6 & 6,49 \\
Serat kasar (\%) & Keterangan: P0 (Kontrol), P1 (5\% Apu-apu), P2 (10\% Apu-apu), P3 (15\% Apu-apu) \\
\multicolumn{4}{c}{ dan P4 (20\% Apu-apu). }
\end{tabular}




\section{Variabel yang diukur}

1. Konsumsi ransum

Perhitungan konsumsi ransum dilakukan setiap minggu dengan cara jumlah ransum yang diberikan dikurangi dengan sisa ransum yang tidak dikonsumsi selama satu minggu. Konsumsi rata-rata ransum dihitung setiap minggu selama 4 minggu. Pada penelitian ini munggunakan rumus konsumsi ransum menurut Rasyaf (1994):

Konsumsi ransum $=\frac{\text { Ransum yang diberikan }(\text { gram })-\text { Ransum yang disisa }(\text { gram })}{\text { Jumlah ayam (ekor) }}$

2. Pertambahan bobot badan

Pengukuran bobot badan ayam kampung super dengan melakukan penimbangan setiap minggu sebelum ayam diberi ransum. Penimbangan dilakukan selama 4 minggu kemudian dirata-ratakan setiap perlakuan pada akhir penelitian. pertambahan bobot badan menurut Bagenal (1978) dengan menggunakan rumus:

PBB: $\mathrm{BB}_{\mathrm{t}}-\mathrm{BB}_{\mathrm{t}-1}$

Keterangan:

PBB = Pertambahan bobot badan (gram/ekor)

$\mathrm{BB}_{\mathrm{t}} \quad=$ Bobot badan akhir (gram/ekor)

$\mathrm{BB}_{\mathrm{t}-1}=$ Bobot badan awal (gram/ekor)

$\mathrm{t}=$ Dalam peternakan ayam biasanya dalam kurang waktu yang sama

3 Konversi ransum

Konversi ransum adalah perbandingan antara rata-rata konsumsi ransum dengan rata-rata pertumbuhan bobot badan yang dihasilkan, semakin rendah konversinya maka semakin bagus nilai suatu ransum. Konversi ransum dapat di hitung menggunakan rumus Bagenal (1978):

$$
\mathrm{FCR}=\frac{\mathrm{X} \mathrm{KR}}{\mathrm{XPBB}}
$$

Keterangan:

FCR = Konversi ransum (gram/ekor) 


$$
\begin{aligned}
& \mathrm{XKR}=\text { Rata- rata konsumsi ransum (gram/ekor) } \\
& \mathrm{XPBB}=\text { Rata-rata petumbuhan bobot badan (gram/ekor) }
\end{aligned}
$$

\section{Analisis Data}

Analisis data yang digunakan pada penelitian adalah analisis sidik ragam dengan metode matematika dari rancangan acak lengkap. Jika perlakuan berpengeruh nyata $(\mathrm{P}<0.05)$ maka dilanjutkan uji wilayah berganda Duncan untuk melihat perbedaan setiap sampel perlakuan. Menggunakan rumus menurut Steel dan Torrie (1995). Dianalisis menggunakan software SPSS IBM 21.

\section{HASIL DAN PEMBAHASAN}

Hasil penelitian selama 4 minggu pada umur 80-118 hari pada ayam kampung super yang mengcakup konsumsi ransum, pertambahan bobot badan dan konversi ransum disajikan pada Tabel 3.

Tabel 3. Rataan konsumsi ransum, pertambahan bobot badan dan konversi ransum ayam kampung super umur 90 - 118 hari.

\begin{tabular}{llllll}
\hline \multirow{2}{*}{ Parameter yang Diukur } & \multicolumn{5}{c}{ Perlakuan } \\
\cline { 2 - 6 } & \multicolumn{1}{c}{ P0 } & \multicolumn{1}{c}{ P1 } & \multicolumn{1}{c}{ P2 } & P3 & P4 \\
\hline Konsumsi ransum (g/e/minggu) & 1.847 & 1.520 & 1.648 & 1.525 & 1.523 \\
Pertumbuhan bobot badan (g/e/minggu) & 250.33 & 212.00 & 202.00 & 138.33 & 173.33 \\
Konversi ransum & 10.43 & 7.47 & 8.43 & 12.17 & 10.12 \\
\hline $\begin{array}{l}\text { Keterangan: P0 (Kontrol), P1 (Apu-apu 5\%), P2 (Apu-apu 10), P3 (Apu-apu 15\%) dan P4 (Apu-apu } \\
\text { 20\%). }\end{array}$
\end{tabular}

\section{Konsumsi Ransum}

Nilai rata-rata konsumsi ransum (gram/ekor/minggu) tertinggi terdapat pada perlakuan P0 (1.847 gram), kemudian diikuti pada perlakuan P2 (1.648 gram), P3 (1.525 gram), P4 (1.523 gram) dan P1 (1.520 gram). Dari hasil analisis sidik ragam menunjukkan bahwa perlakuan tidak berpengaruh nyata $(\mathrm{P}>0,05)$ terhadap konsumsi ransum.

Hasil dari penelitian ini menunjukkan bahwa konsumsi ransum pada perlakuan yang menggunakan apu-apu lebih lebih rendah dari kontrol. Hal ini disebabkan ransum yang terdapat apu-apu (Pistia stratiotes) mengalami perubahan warna, rasa dan bau serta bentuk ransum semakin halus. Sejalan dengan pendapat Yahju (1992) yang melaporkan bahwa ternak unggas lebih menyukai makanan berbutir daripada berbentuk tepung. Ditambahkan oleh Murtidjo (2006) menyatakan bahwa ransum yang berbentuk tepung (mash) cepat 
diserap oleh usus tetapi sulit dimakan karena berdebu (berbentuk tepung) sehingga ayam cenderung tidak bergairah untuk memakannya.

Rendahnya konsumsi ransum pada perlakuan P1 (1,520 gram), (P3 (1.525 gram), P4 (1.523 gram) dikarenakan kandungan serat kasar yang terdapat pada ransum terlalu tinggi P3 (6\%) dan P4 (6.46) dibandingkan perlakuan yang lain sehingga mengakibatkan tingkat kecernaan rendah. Menurut pendapat Wahju (1992) yang menyatakan bahwa ransum yang mengandung serat kasar yang tinggi maka ransum tersebut tidak dapat dicerna sepenuhnya dan menyebabkan tembolok penuh sehingga jumlah konsumsi ransum terbatas.

Penyebab lain rendahnya konsumsi pada perlakuan yang menggunakan apu-apu disebabkan oleh palatabilitas ayam terhadap ransum. Sejalan dengan pendapat Siregar dkk. (1980) yang melaporkan bahwa palatabilitas, kesegaran ransum merupakan faktor yang juga menentukan jumlah ransum yang dikonsumsi dan ransum yang mempunyai cita rasa yang disenangi akan lebih banyak dikonsumsi.

Pemberian ransum pada ayam selain bertujuan meningkatkan pertambahan bobot badan, juga untuk pertumbuhan, perkembangan, penggemukan serta untuk meningkat produksi telur (Wirdateti, dkk, 1993). Penggunaan apu-apu (pistia stratiotes) dengan berbagai level komposisi dalam ransum pada ayam kampung super tidak memberikan perbedaan yang nyata terhadap konsumsi ransum. Hal ini disebabkan jumlah ransum yang dikonsumsi ayam tergantung pada spesies, umur, berat badan, temperatur lingkungan dan tingkat gizi dalam pakan (Rasyaf, 2006).

\section{Pertambahan Bobot Badan}

Nilai rataan pertambahan bobot badan tertinggi pada perlakuan P0 (250.33 gram) kemudian diikuti P1 (212.00 gram), P2 (202.00 gram), P4 (173.33 gram) dan P3 (138.33 gram). Berdasarkan analisis sidik ragam menunjukkan bahwa perlakuan tidak berpengaruh nyata $(\mathrm{P}>0.05)$ terhadap pertambahan bobot badan ayam kampung super.

Hasil uji penelitian, pertambahan bobot badan tertinggi pada P0 ((250.33 gram) kemudian diikuti pada perlakuan P1 (212.00 gram) dan P2 (202.00 gram) sehingga penggunaan apu-apu 5\% sampai 10\% dalam ransum mampu memenuhi kebutuhan ayam kampung super. Hal ini sejalan pendapat Diler (2007) yang menyatakan bahwa tanaman apu-apu (pistia stratiotes) berpotensi dijadikan bahan penyusun ransum karena memiliki nutrisi yang tinggi. 
Pada perlakuan P4 (173.33 gram) dan P3 (138.33 gram) pertambahan bobot badan memiliki nilai terendah bila dibandingkan pada perlakuan P0 ((250.33 gram). Hal ini diduga karena penggunaan apu-apu pada P3 (15\%) dan P4 (10\%), jika dilihat dari formulasi ransum semakin tinggi penggunaan apu-apu maka semakin tinggi pula serat kasarnya. Sebagaimana yang terlihat dari analisis proksimat yang telah dilakukan bahwa apu-apu memiliki kandungan serat kasar sebesar 15,8\%. Hal ini sesuai dengan Handayani A (2017) yang menyatakan bahwa bobot badan dipengaruhi oleh kualitas dan kuantitas ransum yang optimal, perbedaan zat-zat makanan yang terkandung pada ransum berpengaruh pada pertambahan bobot badan yang dihasilkan. Sejalan dengan pendapat Rasyaf (2006) yang menyatakan bobot badan dipengaruhi oleh kualitas ransum yang di konsumsi karena kandungan zat-zat makanan yang seimbang dan cukup sesuai dengan kebutuhan diperlukan untuk pertumbuhan yang optimal.

Tanaman apu-apu (Pistia stratiotes) memiliki kandungan protein kasar yang tinggi sebesar 35,7\%, BETN sebesar 16,6\% tetapi disamping itu memiliki juga serat kasar yang tinggi sebesar 15,8\% sehingga pertumbuhan bobot badan ayam kampung super dari penelitian ini tidak berbeda nyata, meskipun dari penelitian Sutama (2005) menunjukkan bahwa pemberian tepung apu-apu sampai 30\% dalam ransum menurunkan LDL serum dan total kolesterol daging, disamping meningkatkan HDL serum. Pada penelitian ini didapatkan nilai optimum dalam penggunaan apu-apu pada ayam kampung super sebesar 5\% sampai 10\% sebagaimana nilai P1 (212.00 gram) dan P2 (202.00 gram), mendekati P0 (250.33 gram).

\section{Konversi Ransum}

Rata-rata nilai konversi ransum terendah pada penelitian ini diperoleh dari perlakuan P1 (7,47), P2 $(8,43)$ kemudian diikuti berberturut-turut oleh P4 $(10,12)$, P0 $(10,43)$ dan tertinggi pada P3 (12,17). Berdasarkan analisis sidik ragam yang dilakukan menunjukkan bahwa perlakuan tidak berpengaruh nyata $(\mathrm{P}>0,05)$.

Hasil uji menunjukkan nilai konversi ransum pada pemeliharaan ayam kampung super selama 4 minggu menunjukkan bahwa perlakuan P1 dan P2 memiliki nilai konversi ransum yang lebih rendah dibandingkan dengan P0, P4 dan P3. Nilai konversi ransum adalah perbandingan antara rata-rata konsumsi ransum dengan rata-rata pertambahan bobot badan ayam kampung super yang diperoleh selama penelitian berlangsung, konversi ransum salah satuh cara dalam menentukan kualitas ransum. Sejalan dengan Allama, dkk 
(2012) mengatakan bahwa nilai konversi ransum yang rendah menunjukkan bahwa efesiensi penggunaan ransum yang baik, karena semakin efesien ayam mengonsumsi ransum untuk memproduksi daging.

Hasil analisis perlakuan P3 dan P4 memiliki nilai konversi ransum yang tertinggi, hal ini disebabkan keseimbangan ransum, ukuran tubuh, temperatur lingkungan, berat hidup, jenis kelamin serta kandungan serat kasar pada ransum yang tidak maksimal dalam penyerapannya menjadi daging. Hal ini sesuai pendapat Anggorodi (1986) yang menyatakan bahwa nilai konversi ransum dapat dipengaruhi oleh beberapa faktor, diantaranya suhu lingkungan, laju perjalanan ransum melalui alat pencernaan, bentuk fisik dan konsumsi ransum. Ditambahkan dengan James (1992), melaporkan bahwa faktor yang mempengaruhi konversi ransum adalah genetik, jenis dan kualitas ransum, temperature, bahan bukan zat makanan yang digunakan dalam ransum dan manajemen.

Nilai konversi ransum dipengaruhi oleh jumlah konsumsi ransum dan pertambahan bobot badan Usman, (2009). Berdasarkan analisis pada penelitian, konsumsi ransum dan pertumbuhan bobot badan tidak berpengaruh nyata $(\mathrm{P}<0,05)$. Sejalan juga dengan Sulaeman (2014) yang menyatakan bahwa konversi pakan dipengaruhi oleh tingkat konsumsi pakan, daya cerna dan penggunaan zat-zat makanan yang harus seimbang.

\section{KESIMPULAN}

Berdasarkan hasil penelitian mununjukkan bahwa penambahan tepung apu-apu (Pistia stratiotes) dalam ransum ayam kampung super tidak berpengaruh nyata $(\mathrm{P}>0,05)$ terhadap konsumsi ransum, pertambahan bobot badan dan konversi ransum. Tetapi penggunaan pada taraf $5 \%$ dan $10 \%$ apu-apu memberikan hasil yang baik terhadap performa ayam kampung kampung super sehingga mampu mengurangi penggunaan bungkil kedelai dan tepung ikan.

\section{DAFTAR PUSTAKA}

Agustina. 2013. Potensi Ayam Buras Indonesia. Graha Ilmu, Yogyakarta.

Anggorodi, H, R. 1985. Kemajuan Mutakhir Ilmu Makanan Ternak Unggas. Universitas Indonesia Press, Jakarta.

Allama, H., Sofyan, O., Widodo, E., dan Prayogi, H.S. 2012. Pengaruh penggunaan tepung ulat kandang (Alphitobius diaperinus) dalam pakan terhadap penampilan produksi ayam pedaging. Jurnal Ilmu-Ilmu Peternakan, 22(3), 1-8. 
Bagenal, T. B. 1978. Aspects of fish fecubdity. ecology of fresh water fish production. black, well scientific publication, oxfoard. diler, z. a., tekinay. guroydansoyuturk. 2007. effects of pistia stratiotes on the growth feed intake and body composition of common carp cyprinuscarpio 1. Journal of Biological Scinces, 7(92), 305-308.

Hardjosworo, P S. 2000. Meningkatkan Produksi Daging Unggas. Penebar Swadaya, Jakarta.

Handayani A. 2017. Penambahan tepung kunyit (Curcuma domestica) dalam Ransum Terhadap Performans Itik Hibrida Fase Grower. Skripsi. Program studi Peternakan. Fakultas Peternakan Universitas Nusantara PGRI, Kediri.

James, R. G. 1992. Livestock and Foultry Production. 4th Ed. The Avi Publication Co. Inc, Westpost, Connecticut.

Murtidjo, B. A. 2006. Pedoman Meramu Pakan Unggas. Kanisius, Yogyakarta.

National Research Council. 1994. Nutrient Requirement of Poultry. National Academy Press. Washington D.C.

Nitis, I. M. 1980. Makanan Ternak Salah Satu Sarana Untuk Meningkatkan Produksi Ternak. Pidato Ilmiah Pengukuhan Guru Besar Dalam Ilmu Makanan Ternak Fakultas Kedokteran Hewan dan Peternakan. Universitas Udayana, Bali.

Rasyaf, M. 2006. Beternak Ayam Pedaging. Penebar Swadaya, Jakarta. . 1992. Memelihara Ayam Buras. Kanisius, Yogyakarta.

Steel, R. G. D., dan Torrie, J.H. 1995. Prinsip dan Prosedur Statistika: Suatu Pendekatan Biometrik. Terjemahan B. Sumantri. Gramedia Pustaka Utama, Jakarta.

Sulaeman, Indrawati, dan Sujana. 2015. Pengaruh Pemberian Tepung Ampas Kunyit (Curcuma domestica val) dalam Ransum terhadap Performa Produksi Telur Puyuh (Cortunix-cortunix japonica). Student e-Journal, 4(4).

Sutama, S. 2005. Pengaruh suplementasi kapi-kapu (Pistia strtiotes L) dalam ransum terhadap kolestrol pada serum dan daging ayam kampung. Majalah Ilmiah Peternakan, 8(2).

Siregar, A, P., M. Sabrani dan P. Suroprawiro. 1980. Tehnik Beternak Ayam Pedaging di Indonesia. Margie Group, Jakarta.

Tillman. A. D., Hartadi., H., Reksohaddiprodjo, H., Prawirokusumo, S., dan Lebdosoekojo, S. 1991. Ilmu Makanan Ternak Dasar. Gadjah Mada University Press, Yogyakarta.

Usman. 2009. Pertumbuhan Ayam Buras Periode Grower Melalui Pemberian Tepung Biji Buah Merah (Pandanus conoideus LAMK) Sebagai Pakan Alternatif. Prosiding Seminar Nasional Teknologi Peternakan dan Veteriner. Balai Pengkajian Teknologi Pertanian Papua.

Widodo, J. 2014. Bibit ayam kampung super. http://jack-jogja.blogspot.com/. (20 Desember 2018).

Widiati, R., A. Rahman, A., and Sudaryati, S. 2014. Semi Intensive Native Chicken Farming As An Alternative Establish Food Sovereignity of Rural Communities dalam Proceeding Seminar Sustainable Livestock Production Based on Local Resources in the Global Climate Change Era: Prospect and Chalanges. Faculty of Animal Husbandry, University of Brawijaya. Malang, Indonesia.

Wahyu, J. 1992. Ilmu Nutrisi Unggas. Gajah Mada University Press, Yogyakarta.

Wirdateti., Wawo, A. H., dan Naiola, B.P. 1993. Usaha peningkatan produktivitas ayam buras di lahan kering desa Pulutan wonosari, kabupaten Gunung Kidul. Jurnal IlmuIlmu Peternakan, 15 (2). 